\title{
THE ROLE OF UNION SUPPORT IN COPING WITH JOB INSECURITY: A STUDY AMONG UNION MEMBERS FROM THREE EUROPEAN COUNTRIES
}

\author{
SJOERD GOSLINGA \\ s.goslinga@belastingdienst.nl \\ Research Department \\ Belastingdienst/FIOD-ECD \\ Haarlem, The Netherlands \\ JOHNNY HELLGREN \\ Department of Psychology \\ Stockholm University \\ Stockholm, Sweden \\ ANTONIO CHIRUMBOLO \\ Department of Psychology \\ University of Rome "La Sapienza" \\ Rome, Italy \\ HANS DE WITTE \\ Department of Psychology \\ Catholic University of Leuven \\ Leuven, Belgium \\ KATHARINA NÄSWALL \\ MAGNUS SVERKE \\ Department of Psychology \\ Stockholm University \\ Stockholm, Sweden
}

\begin{abstract}
Acknowledgements: The research reported here comes from a European project ("European unions in the wake of flexible production: how can the negative effects of job insecurity for employee attitudes and well-being be mitigated?"), financed by a grant to Magnus Sverke from the Swedish National Institute for Working Life through the Joint Programme for Working Life Research in Europe (SALTSA). Data collections in the participating countries were made possible through financial support as follows: Italy: CGIL-Natzionale, The Netherlands: the National Christian Trade Union Federation (CNV), Sweden: the Swedish Council for Work Life Research, the KF Group, the Salaried Employees' Union, and the Cooperative Employees Association. An earlier version of the manuscript was presented at the XXVII International Congress of Psychology, July 2000, Stockholm,
\end{abstract} Sweden.

\begin{abstract}
The present study examines the potential moderating role of union support in the relationship between job insecurity and work-related attitudes and well-being of unionised employees. Survey data collected among union members from three European countries (The Netherlands, Italy and Sweden) indicate that job insecurity is associated with reduced levels of job satisfaction, well-being and organisational commitment. Contrary to expectations, union support moderated neither the effect of job insecurity on job satisfaction nor its effect on wellbeing. However, in two countries a moderating effect of union support on relation between the job insecurity and organisational commitment was found.
\end{abstract}

\section{OPSOMMING}

Die huidige studie ondersoek die potensiële modererende rol van vakbond ondersteuning in die verhouding tussen werksonsekerheid en werksverwante houdings en welstand van werknemers wat aan 'n, vakbond behoort. Opname data wat ingesamel is tussen vakbond lede van drie Europese lande (Nederland, Italië en Swede) toon dat werksonsekerheid geassosieer word met verlaagde vlakke van werkstevredenheid, welstand en organisasieverbondenheid. Teen verwagting, het vakbond ondersteuning nie die effek van werksonsekerheid op wekstevredenheid of welstand gemodereer nie. Daar is egter in twee lande ' $n$, moderende effek van vakbond ondersteuning op die verwantskap tussen werksonsekerheid en organisasie gebondenheid gevind.

\begin{abstract}
The past decades have witnessed a growth of the number of employees who are confronted with (periods of) job insecurity. The 1980s saw many large scale reorganisations and downsizing efforts that meant mass layoffs in many firms in the industrialized countries. In the 1990s the need for more (internal) flexibility of firms resulted in a growth of temporary or contingent contracts (e.g. Purcell \& Purcell, 1998). Job insecurity, often defined as the perceived threat of job loss or the loss of valued aspects of a job, is generally viewed as a highly stressful experience for employees (Hartley, Jacobson, Klandermans \& Van Vuuren, 1991).
\end{abstract}

Requests for copies should be addressed to: A Chirumbolo, a.chirumbolo@unich.it
Research shows that job insecurity has detrimental effects for both employees and (the productivity and efficiency of) organisations (see also Sverke, Hellgren \& Näswall, 2002 for a review). Job insecurity is, first of all, related to several work related attitudes and behaviours of employees. Relationships have been found between job insecurity and reduced job satisfaction (Ashford, Lee \& Bobko, 1989; De Witte \& Näswall, 2003; Hellgren, Sverke \& Isaksson, 1999; Kerkhof, Winder, Tamis, Te Brake \& Klandermans, 2000; Lim, 1996; Van Vuuren, Klandermans, Jacobson \& Hartley, 1991; Van Vuuren, Van Gastel \& Klandermans, 1988), reduced organisational commitment (Ashford et al., 1989; Chirumbolo \& Hellgren, 
2003; Rosenblatt \& Ruvio, 1996; Rosenblatt, Talmud \& Ruvio, 1999;), reduced organisational trust (Ashford et al., 1989; Kerkhof et al., 2000), the intention to leave the organisation (Dekker \& Schaufeli, 1995; Hellgren et al., 1999; Sverke \& Goslinga, 2003), and pro-active job search and noncooperative behaviour at work (Lim, 1996). Furthermore, job insecurity is negatively related to employees' well-being and health (De Witte, 1999). Several studies show that job insecure employees report lower levels of psychological well-being than secure employees (Burchell, 1994; Büssing, 1999; De Witte, 1999; Hellgren et al., 1999; Lim, 1996; Roskies \& LouisGuerin, 1990; Van Vuuren et al., 1991). Feelings of mental, emotional and physical exhaustion (burnout) have also been found to be related to job insecurity (Dekker \& Schaufeli, 1995; Kinnunen, Mauno, Nätti \& Happonen, 1999; Landsbergis, 1988) and a number of studies indicate that employees who are insecure about their job report physical health complaints more often than employees who feel secure about the future of their job (Burchell, 1994; Heaney, Israel \& House, 1994; Hellgren et al., 1999). Most of the research on the relationship between job insecurity and its outcomes is correlational or cross-sectional. However, all longitudinal studies that have been conducted so far, although limited in number, provide support for the causal direction between job insecurity and the work and health related variables (Burchell, 1994; Hellgren \& Sverke, 2003; Van Vuuren, 1990).

Research has also focussed on the ways in which employees cope with job insecurity and on factors that possibly protect or buffer against the negative consequences of job insecurity. The studies aimed at identifying moderators in the relationship between job insecurity and its consequences are still relatively scarce, especially given the number of studies in which the detrimental effects of job insecurity have been demonstrated. Three factors distinguished by Greenhalgh and Rosenblatt (1984) have guided this line of research. The first moderator Greenhalgh and Rosenblatt (1984) put forward was individual differences. The idea here is that certain personal or personality characteristics determine whether, or how effectively, people cope with job insecurity. However, the studies in which attention has explicitly been devoted to the influence of these characteristics on the way people cope with job insecurity show far from unequivocal results (Hellgren et al., 1999; Roskies, Louis-Guerin \& Fournier, 1993).

The second moderator suggested by Greenhalgh and Rosenblatt (1984) is the extent to which people perceive themselves to be dependent on their job for the fulfilment of important needs. The reasoning here is that the (anticipated) loss of a job or certain job features will have more severe effects when there is more at stake. Several factors are deemed important in this respect, such as the proportion of the family income provided by the job and the available alternatives on the job market. One study that indirectly investigated this question, however, provided no support for the assumption that available alternatives on the job market mitigate the negative effects of job insecurity. That is, no significant interaction effect of perceived alternatives on the job market and job insecurity on employee behaviour was found (Kerkhof et al., 2000).

The third factor Greenhalgh and Rosenblatt (1984) expected to have a moderating effect is the support from others in the social environment. The literature on other sources of stress at work (for example role conflict and role ambiguity) provides evidence of a moderating effect of social support on the relation between stress and stress reactions. Based on this, Greenhalgh and Rosenblatt (1984) hypothesized a buffering effect of social support on the relation between job insecurity and the negative consequences for individual employees. In line with this, Lim (1996) found evidence for moderating effects of both work-based social support (support from colleagues and supervisors) and non work-based social support (support from family and friends) on the relationship between job insecurity and several outcome variables. Lim's (1996) study shows that support provided by others at work contributes to buffering insecure employees against job dissatisfaction, proactive job search and noncompliant behaviours at work. Additionally, support derived from family and friends can buffer insecure employees against negative effects such as life dissatisfaction. Büssing (1999) reports similar results. His study shows that support from friends has a (stronger) moderating effect on indicators of well-being and health, while support from supervisor and colleagues has a moderating effect on job (dis-)satisfaction. Thus, support seems to provide a powerful moderator of the associations between job insecurity and different outcome variables.

Like previous research, the present study also examines the role of support in the relation between job insecurity and negative outcomes for employees. The researchers will investigate whether support from one's labour union has an effect on the relationship between job insecurity and two work-related attitudes (job satisfaction and organisational commitment), and well-being. The researchers are not aware of any studies examining the role labour unions play or might play for employees who have to cope with job insecurity. Attention has been given to the impact of job insecurity on the process of joining a labour union (Bender \& Sloane, 1999) and to the effect of job insecurity on union members' contacts and experiences with the union and participation in union activities (Goslinga, 2000; Van Vuuren et al., 1991).

Potentially, the researchers believe, labour unions could be an important source of information and support for members (and perhaps for employees in general) who are faced with job insecurity. A first reason is that unions are not responsible for the threat of job loss but are usually informed about developments and (planned) changes in organisations and often involved in organisational change processes. Research on information search behaviours of employees in firms that undergo restructuring or downsizing suggests that workers tend to avoid parties responsible for the caused anxieties. Rather, they seek out reliable third parties for information, because interaction with colleagues and supervisors may in itself be stressful (Casey, Miller \& Johnson, 1997). Labour unions might function as a third party that members can approach when they are confronted with job insecurity and in need of reliable information and support. Secondly, labour unions have the resources and knowledge to actually help their members, for instance, by providing information about and assistance with legal matters.

The present study utilises a measure of union support that was developed by Shore, Tetrick, Sinclair \& Newton (1994). Their work, in turn, was based on Eisenberger, Huntington, Hutchinson and Sowa's (1986) theory of perceived organisational support. This conceptualisation of support is somewhat different from social support as used in previous job insecurity studies. The idea of perceived organisational support is based on social exchange theory. Perceived organisational support reflects employees' general beliefs concerning the extent to which the organisation values the employees' contributions and cares about their well-being. Similarly, perceived union support reflects the member's perception that the union is supportive and committed to its members. The purpose of the present study is to examine whether perceived union support moderates the relationship between job insecurity and its outcomes.

To sum up, the hypotheses for the present study are: 1) job insecurity has a negative effect on job satisfaction, organisational commitment, and well-being; 2) perceived support from the union buffers or moderates the relationship between job insecurity and job satisfaction, organisational commitment, and well-being. In other words, job insecurity will have less detrimental effects for 
job satisfaction, organisational commitment, and well-being when perceived support from the union is high. These hypotheses will be tested in three samples of union members from three different countries (The Netherlands, Italy and Sweden). The researchers do not specify hypotheses regarding differences between countries. Rather, the reasearchers expect similar results in the different countries.

\section{RESEARCH DESIGN}

\section{Participants and procedures}

The dataset used in this study was composed for a broader European project focusing on the role of labour unions in the new flexible labour market (see Sverke, Hellgren, Näswall, Chirumbolo, De Witte \& Goslinga, 2001). Questionnaire data were collected either before (The Netherlands) or after (Italy, Sweden) initiation of the project. Effort was made to obtain comparable data from all countries. However, the fact that not all data collections were specifically tailored for the project explains why there are small differences in operationalisations between countries.

\section{The Netherlands}

For this study the researchers used data collected within a longitudinal panel-survey among members of the largest trade unions affiliated with the National Christian Trade Union Federation, the CNV. Among these unions are six public sector unions and three private sector unions. Data came from one wave of the panel survey, and were collected in the summer of 1999. Members were interviewed by telephone. The response rate was $50 \%$. The sample was limited to members with a paid job $(N=611)$. The majority of the respondents were male $(72,5 \%)$. The mean age was 42,8 years, ranging between 16 and 79 years, and the average length of union membership 14,3 years, ranging between 0 and 50 years. Most members had a full-time job $(79,7 \%)$ and $10,5 \%$ were temporary workers.

\section{Italy}

For this study data were collected from May to July 2000. Questionnaires were administered to 476 workers, mainly in small groups and at their workplace. For the present study the sample was limited to union members $(N=296)$. The majority of respondents were males $(68,7 \%)$, and their age ranged rom 22 to 59 years $(\mathrm{M}=40,6)$. The majority had a full time job $(93,5 \%)$ and $7,5 \%$ had a temporary job. On average, participants had their current job for 14,9 years (ranging from less than a year to 37 years).

\section{Sweden}

Data were taken from a national sample of blue-collar workers from the Swedish Municipal Workers Union (SKAF) affiliated with the Swedish Trade Union Confederation (LO). The sample was randomly selected from a total population of 370,590 members. Questionnaires were sent out to 2,564 workers, and a total of 1,923 usable questionnaires were returned (a response rate of $75 \%$ ). Cases with one or more missing values in the dataset were excluded, resulting in a sample size of 1829 union members. The mean age of the respondents was 45 years, ranging between 19 and 75 years. Average length of membership in the union ranged from 1 to 45 years $(M=16,4)$. The majority of the sample were female $(78,0 \%)$. All respondents had a paid job. Half of them were employed full time $(46,9 \%)$ and $7,3 \%$ were temporary workers. Organisational tenure ranged from 1 to 45 years $(\mathrm{M}=14,3)$.

\section{Measures}

Job insecurity

Job insecurity was assessed with five items in all three data sets.

Three of these items were based on the measurement scale used by Ashford et al. (1989), and two further items were developed by De Witte (2000) (e.g., "I am afraid I will get fired", "I think I might get fired in the near future"). The response alternatives ranged from 1 (disagree) to 5 (agree). A high score on any of the items indicates high perceived job insecurity.

\section{Perceived Union Support}

This variable was measured using a five-item scale in all samples, which is adapted from Shore et al. (1994) (e.g., "I can always call upon my union with questions or problems", "My union appreciates my opinion"). Response alternatives range from 1 (disagree) to 5 (agree), so that a high score indicates high perceived union support. Previous research with this measure in The Netherlands yielded a good reliability for the scale (Goslinga, 1996; 2004). In Sweden, union support was measured with four of the five items used in Italy and the Netherlands.

\section{Job Satisfaction}

Job satisfaction was measured using various numbers of items in the different data sets. Five items were used in Italy and three of these were used in the Swedish and Dutch data sets (e.g., "I am satisfied with my job", "I enjoy being at my job"). Three of the five items were developed by Hellgren, Sjöberg \& Sverke (1997), based on Brayfield and Roth (1951); the remaining two were developed by De Witte (2000). There were five response alternatives ranging from 1 (disagree) to 5 (agree), and a high score on any item represents satisfaction with the job.

\section{Organisational Commitment}

The same five items were used in all three data sets, reflecting affective organisational commitment (Allen \& Meyer, 1990; Meyer, Allen \& Smith, 1993) (e.g., "I feel a strong sense of belonging to my organisation", "This organisation has a great deal of personal meaning to me"). The response scale ranged from 1 (disagree) to 5 (agree).

TABLE 1

MEANS, STANDARD DEVIATIONS AND INTERCORRELATIONS

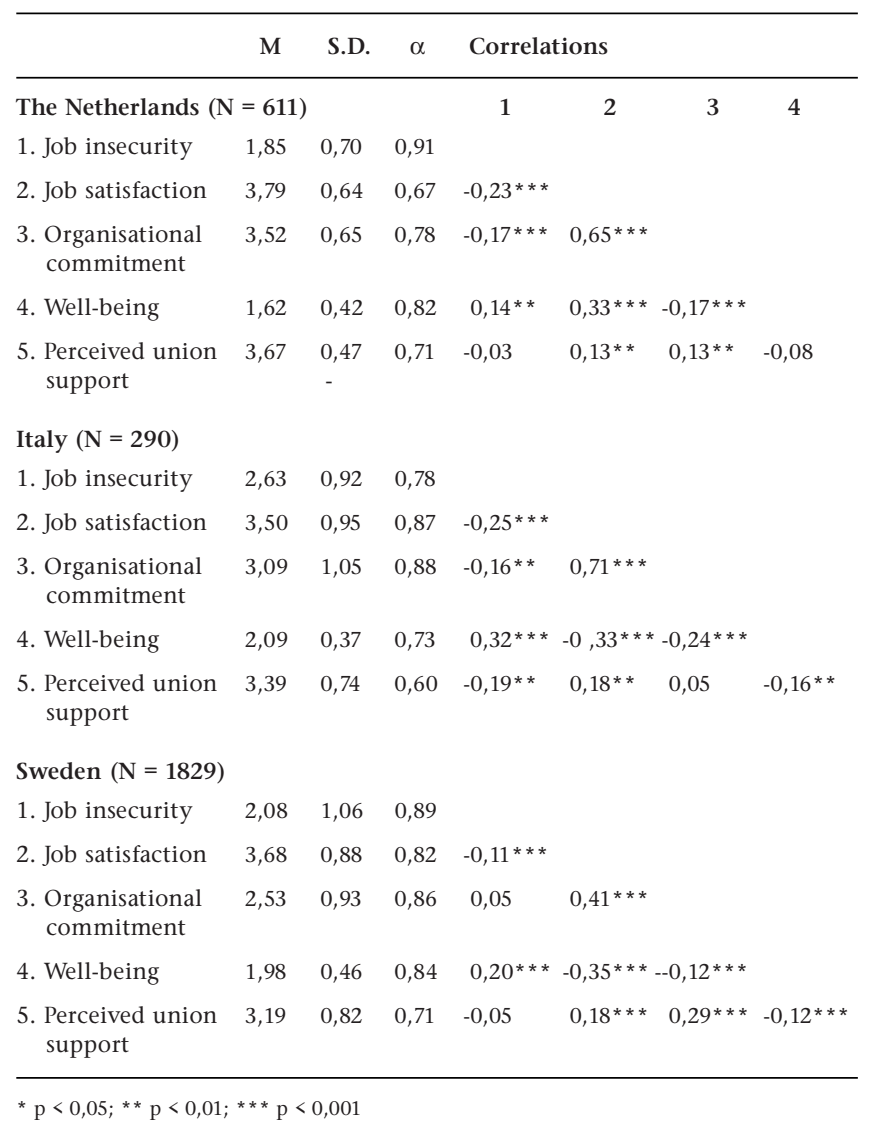




\section{Well-being}

The 12-item version of the General Health Questionnaire (GHQ; Goldberg, 1979) was used in all three countries. Answers were scored on 4-point scales and a higher score indicates lower well-being.

\section{Scale reliabilities}

Scale reliabilities were acceptable (Cronbach's alpha above 0,70 ) in almost all cases (Table 1). Exceptions were the job satisfaction measure in The Netherlands and the perceived union support measure in Italy. However, in both cases scale reliabilities did not improve when one or more items were removed from the scale. For that reason, as well as in order to secure comparability between the different samples, the scales were not changed.

\section{RESULTS}

The pattern of correlations was similar for the three samples (Table 1). In line with our first hypothesis, we found that job insecurity was negatively related to job satisfaction and wellbeing in all three countries. In both the Dutch and Italian samples, job insecurity was also negatively related to organisational commitment. In the Swedish sample however, the relationship between job insecurity and organisational commitment failed to reach significance. For the Italian sample job insecurity was also negatively related to perceived union support, indicating that higher levels of perceived union support were associated with lower levels of job insecurity. The correlation between perceived union support and job insecurity was not significant in the Dutch and Swedish samples.
Correlations between job satisfaction and organisational commitment were significant in all three samples, ranging from 0,41 (Sweden) to 0,71 (Italy) ( $p<0,001$ ). In each sample both job satisfaction and organisational commitment were significantly related to well-being, indicating that higher levels of job satisfaction and organisational commitment were associated with higher well-being. The correlations between job satisfaction and well-being were very consistent, as they ranged between $-0,33$ (The Netherlands and Italy) and $-0,35$ (Sweden) ( $p<0,001)$; while the correlations between organisational commitment and well-being ranged between 0,12 (Sweden) and $-0,24$ (Italy) ( $p<0,001$ ). Perceived union support was positively related to both job satisfaction and organisational commitment in the Dutch and Swedish samples. In other words, when members perceived more support from the union, higher levels of job satisfaction and organisational commitment were reported. In the Italian sample results were slightly different: perceived union support was positively related to job satisfaction, but not to organisational commitment. The correlations between perceived union support and well-being were significant in the Italian as well as the Swedish sample, indicating that more support from the union was associated with higher levels of well-being. However, this relationship was absent in the Dutch sample (Table 1).

In order to examine the expected moderating effect of perceived union support on the relationship between job insecurity and the three outcome variables, hierarchical regression analyses were performed. The variables were entered in three steps: first, job insecurity was entered, then perceived union support was added to the equations and, finally, the interaction between perceived union support and job insecurity was entered. Before conducting the analyses, both job

TABLe 2

RESULTS OF HIERARCHICAL REGRESSION ANALYSES OF JOB SATISFACTION, ORGANIATIONAL COMMITMENT AND WELL BEING ON ANTECEDENTS (STANDARDISED REGRESSION COEFFICIENTS)

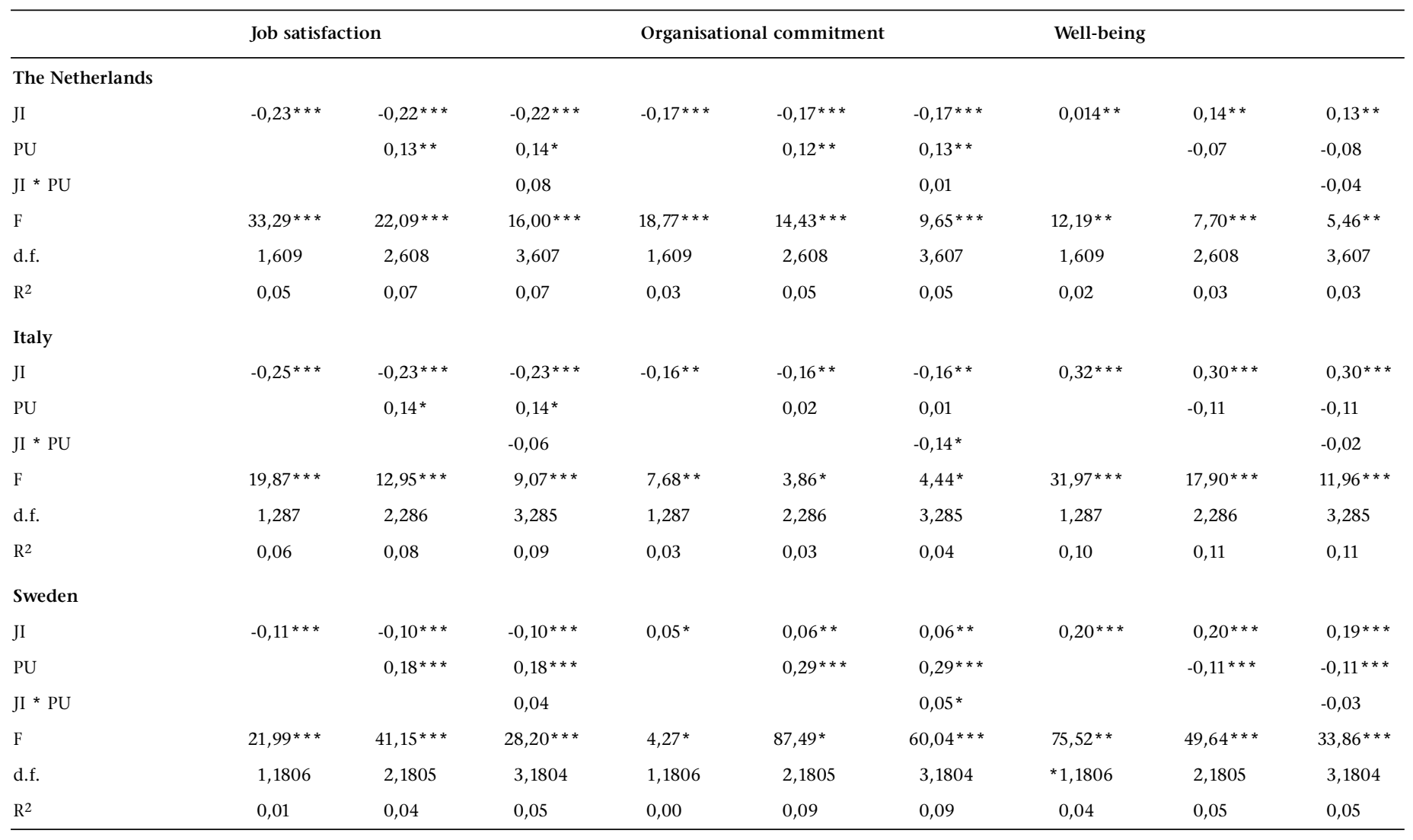

${ }^{*} \mathrm{p}<0,05 ; * * \mathrm{p}<0,01 ; * * * \mathrm{p}<0,001$

$\mathrm{JI}=\mathrm{Job}$ insecurity $\mathrm{PU}=$ Perceived union support 
insecurity and perceived union support were first centred (that is, the mean was set to zero without affecting the standard deviation). Next, the two centred predictor variables were multiplied to form the interaction term (see Aiken \& West, 1991, for more information on this procedure). This was done separately for each sample (Table 2).

In the first step, a significant main effect of job insecurity on all three outcome variables in all three samples was found. As expected, an increase in job insecurity predicted reduced levels of job satisfaction, reduced levels of organisational commitment, and reduced levels of well-being. However, in the Swedish sample the effect of job insecurity on organisational commitment was positive, indicating that an increase in job insecurity predicted higher levels of organisational commitment. Adding perceived union support to the regression equations showed significant main effects of perceived union support on both job satisfaction and organisational commitment in the Dutch as well as the Swedish sample. For the Italian sample, we found a significant main effect of perceived union support on job satisfaction, but not on organisational commitment. Only in the Swedish sample a significant main effect of perceived union support on well-being emerged (Table 2 ). In all cases, the main effect of job insecurity on the dependent variables was unaffected after inclusion of perceived union support in the regression equations.

Next, the cross-product term representing the interaction between job insecurity and perceived union support was entered in the regression equations. The interaction term had no significant beta-weight in the models predicting job satisfaction nor the models predicting well-being in any of the samples. Thus, contrary to our expectations, the effect of job insecurity on job satisfaction and on well-being was not moderated by perceived union support. The interaction term was significant in both the Italian and Swedish sample in the model predicting differences in organisational commitment, but failed to reach significance in the Dutch sample. Thus, the effect of job insecurity on organisational commitment was moderated by perceived union support in the Italian and Swedish samples.

To examine the nature of the interaction effects, predicted values for participants who scored one standard deviation above or below the mean on each variable were calculated. Figure 1 depicts the results for the Italian sample and Figure 2 for the Swedish sample. We expected that increased feelings of job insecurity would only negatively affect organisational commitment for union members whose perceived union support was low, whereas for union members who experienced high support from their union, increased feelings of job insecurity would not affect organisational commitment (i.e., the union's support would have a buffering effect). Contrary to our expectations, however, a different pattern emerged in both countries.

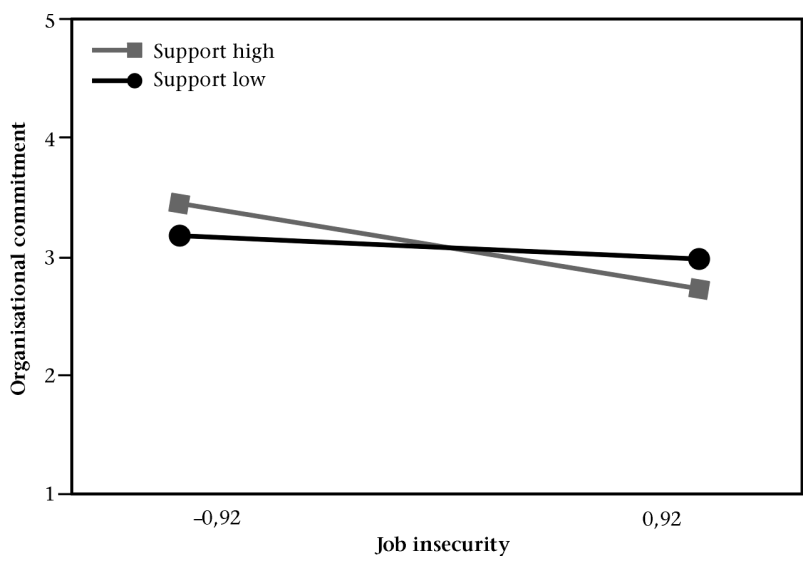

Figure 1: Organisational commitment as a function of perceived union support and job insecurity for the Italian sample

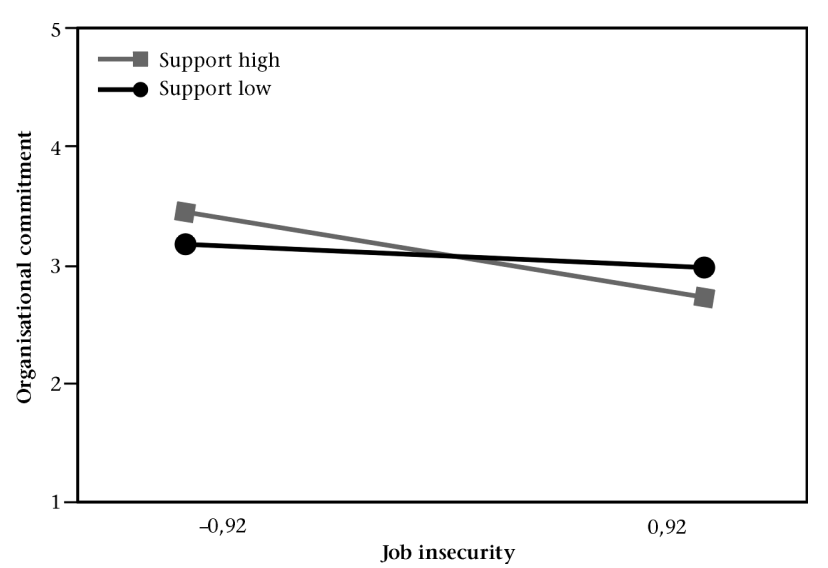

Figure 2: Organisational commitment as a function of perceived union support and job insecurity for the Swedish sample.

For both the Italian and Swedish sample, we found that levels of organisational commitment were stable when job insecurity increased for participants who perceived low support from their union. In the Italian sample, organisational commitment decreased when job insecurity increased among participants who perceived high union support (Figure 1). In contrast, in the Swedish sample, organisational commitment increased when job insecurity increased among participants who perceived high union support (Figure 2).

\section{DISCUSSION}

The results of this study first of all replicate previous research and confirm job insecurity to be an important source of stress for employees (cf. Hartley et al., 1991). In our data, union members who experienced high levels of job insecurity reported reduced levels of job satisfaction, organisational commitment (except for the Swedish sample), and well-being. Given that job insecurity appears to have detrimental consequences, the major purpose of this study was to investigate whether the support union members perceive to get from their union has a moderating effect on the relationships between job insecurity on the one hand and job satisfaction, organisational commitment and well-being on the other hand. Previous research found that personal workbased social support (support from colleagues or supervisor) moderates the relationship between job insecurity and job satisfaction, and that non work-based social support (support from family and friends) moderates the relationship between job insecurity and indicators of well-being (cf. Lim, 1996). The question whether social support also moderates the relationship between job insecurity and organisational commitment had not been addressed previously. However, Lim (1996) reports a moderating effect of work-based social support on the relationship between job insecurity and proactive job search. Since organisational commitment and organisational turnover intentions are closely related (Mathieu \& Zajac, 1990), a moderating effect of social support on the association between job insecurity and organisational commitment might be expected.

However, in the present study, no buffering effects of perceived union support were found; neither on the relationship between job insecurity and job satisfaction, nor on the relationship between job insecurity and well-being. This held true for all three samples. While the researchers obtained small moderating effects of perceived union support on the relationship between job insecurity and organisational commitment in two of the samples (Italy and Sweden), nothing was found in the third sample (The Netherlands). Closer examination of the interaction effects, 
however, revealed that the effects do not support the expected buffering effect. Rather, in both the Italian and Swedish samples, organisational commitment was relatively stable when job insecurity increased and support from the union was low, when a decrease in commitment levels was expected. Moreover, in the Italian sample, organisational commitment decreased, while in the Swedish sample organisational commitment increased, when job insecurity was higher among those members who perceived high support from the union. Perhaps these results reflect differences in industrial relations systems and the meaning of labour unions and labour union membership between countries. Italy is a country with a fairly low union density rate compared to other European countries, with approximately 39\% union members in the labour force. Moreover, Italian industrial relations are, more than the other two countries in this study, characterized by conflicts and disputes (Regalia \& Regini, 1998). Faced with the threat of losing jobs, supported union members might psychologically withdraw from the organisation, which could explain the decrease in organisational commitment. If the union opposes the decisions made by the organisation's management and is in conflict with management, reduced commitment to the organisation is what we would expect from committed union members (Angle \& Perry, 1986). According to the social exchange perspective, union commitment is reflected in the level of perceived union support (Shore et al., 1994). In contrast, in Sweden union density is very high (approximately 83\% in 1995) and industrial relations in Sweden often serve as an example of successful cooperative industrial relations (Kjellberg, 1998). Being a committed union member faced with the threat of job loss appears to result in increased organisational commitment. This might be reflective of increased effort to help the organisation to overcome difficult times.

The fact that the reseachers did not find the expected buffering effect of perceived union support might be attributed to the type of support we assessed with the measure used in our study. Perceived union support, like perceived organisational support, taps a general feeling of support provided by the organisation. This measure does not directly concern personal support from other individuals, such as other union members, union officials or union representatives. Cohen and Wills (1985) concluded after reviewing the literature on the role of support in the relation between stress and well-being, that with more general measures of support generally no moderating effects are obtained, rather, main effects are. That is, a general feeling that one is supported or integrated in a large social network appears to have a positive main effect on well-being, but does not reduce the negative effects of stress. Evidence for a buffering effect is typically obtained when the support measure captures interpersonal resources that are responsive to the needs elicited by the stressful event (Cohen \& Wills, 1985). Previous studies on the role of support in the relation between job insecurity and its outcomes used the latter type of measures. In these studies, evidence for a buffering effect of social support was found (Lim, 1996). In addition, feeling supported by a union shop steward appears to have a buffering effect on the relation between other stressors (role conflict and role ambiguity) and strains (Fried \& Tiegs, 1993). Thus, a question that deserves further attention is whether support provided by individual union representatives or shop stewards has a buffering effect on the relation between jobinsecurity and its outcomes.

Taken together, evidence suggests that integration in a union, as a supportive social network, has a positive effect on workrelated attitudes and well-being of employees. In our data, general feelings of union support had positive main effects on job satisfaction in all three samples, on organisational commitment in two samples, and on well-being in one sample.
These results stress the importance of labour unions as a supportive social network for union members. In previous studies beneficial consequences of union presence have also been observed. That is, union members were found to report higher levels of organisational commitment and work intensity and were less prone to leave the organisation than nonmembers (cf. Sverke \& Hellgren, 2001). The present study expands these findings by showing that not only mere integration in the union has positive effects on work-related attitudes, but that the level of integration also matters.

To conclude, the results obtained in this study reveal that general feelings of union support do not function as a buffer between job insecurity and work-related and health-related outcomes. These results are congruent with a study that compared union members with non-members and found that union membership itself does not buffer employees against the negative outcomes of job insecurity for employee wellbeing (Dekker \& Schaufeli, 1995). Nevertheless, these results add to our understanding of the role of the union by showing that more general support from the union does have beneficial effects, although it does not function as a buffer against the negative consequences of job insecurity. Clearly, in order to fully understand the role of the union for union members faced with job insecurity more research is needed. Further examination of the type and content of the support employees need and value could yield information that might help unions and management to design and provide a supportive environment for employees in firms that undergo restructuring or downsizing, or are otherwise confronted with feelings of job insecurity.

\section{REFERENCES}

Aiken, L.S. \& West, S.G. (1991). Multiple Regression: testing and interpreting interactions. Newbury Park, CA: Sage.

Allen, N.J. \& Meyer, J.P. (1990). The measurement and antecedents of affective, continuance and normative commitment to the organization. Journal of Occupational Psychology, 63, 1-18.

Angle, H.L. \& Perry, J.L. (1986). Dual commitment and labormanagement relationship climates. Academy of Management Journal, 29, 31-50.

Ashford, S.J., Lee, C. \& Bobko, P. (1989). Content, causes, and consequences of job insecurity: A theory-based measure and substantive test. Academy of Management Journal, 4, 803-829.

Bender, K.A. \& Sloane, P.J. (1999). Trade union membership, tenure and the level of job insecurity. Applied Economics, 31, 123-135.

Brayfield, A.H. \& Rothe, H.F. (1951). An index of job satisfaction. Journal of Applied Psychology, 35, 307-311.

Burchell, B. (1994). The effects of labour market position, job insecurity and unemployment on psychological health. In D. Gallie, C. Marsh, \& C. Vogler (Eds.). Social change and the experience of unemployment. (pp. 188-212). Oxford: University Press.

Büssing, A. (1999). Can control at work and social support moderate psychological consequences of job insecurity? Results from a quasi experimental study in the steel industry. European Journal of Work and Organizational Psychology, 8, 219-242.

Casey, M.K., Miller, V.D. \& Johnson, J.R. (1997). Survivors' information seeking following a reduction in workforce. Communication Research, 24, 755-781.

Chirumbolo, A. \& Hellgren, J. (2003). Individual and organizational consequences of job insecurity: a European study. Economic and Industrial Democracy, 24, 217-240.

Cohen, S. \& Wills, T.A. (1985). Stress, social support and the buffering hypothesis. Psychological Bulletin, 98, 310-357.

Dekker, S. \& Schaufeli, W. (1995). The effects of job insecurity on psychological health and withdrawal: a longitudinal study. Australian Psychologist, 30, 57-63. 
De Witte, H. (1999). Job insecurity and psychological well-being: Review of the literature and exploration of some unresolved issues. European Journal of Work and Organizational Psychology, 8, 155-177.

De Witte, H. (2000). Arbeidsethos en jobonzekerheid: antecedenten en consequenties voor het welzijn, de arbeidstevredenheid en de inzet van werknemers. In: $\mathrm{R}$. Bouwen, K. De Witte, H. De Witte, \& T, Taillieu (Eds.). Tussen groep en gemeenschap. Liber amicorum voor prof. dr. L. Lagrou. (pp. 325-350). Leuven: Garant.

De Witte, H. \& Näswall, K. (2003). 'Objective' versus 'subjective' job insecurity: consequences of temporary work for job satisfaction and organizational commitment in four European countries. Economic and Industrial Democracy, 24, 149-188.

Eisenberger, R., Huntington, R., Hutchinson, S. \& Sowa, D. (1986). Perceived organizational support. Journal of Applied Psychology, 71, 500-507.

Fried, Y. \& Tiegs, R.B. (1993). The main effect model versus buffering model of shop steward support: A study of rankand-file auto workers in the U.S.A. Journal of Organizational Behavior, 14, 481-493.

Goldberg, D. (1979). Manual of the General Health Questionnaire. Windsor: National Foundation for Educational Research.

Goslinga, S. (1996). Voor wat hoort wat: een ruiltheoretische benadering van vakbondsbinding. Paper presented at the WESWA congress, Utrecht, The Netherlands.

Goslinga, S. (2000). Arbeidsplaatsonzekerheid, vakbondsparticipatie en vakbondsdienstverlening. Tijdschrift voor Arbeidsvraagstukken, 16, 164-175.

Goslinga, S. (2004). Betrokkenheid, participatie en ledenverloop in vakbonden. Ph.D. thesis, Vrije Universiteit, Amsterdam, The Netherlands.

Greenhalgh, L. \& Rosenblatt, Z. (1984). Job insecurity: toward conceptual clarity. Academy of Management Review, 9, 438-448.

Hartley, J., Jacobson, D., Klandermans, B. \& van Vuuren, T. (1991). Job insecurity: Coping with jobs at risk. London: Sage.

Heaney, C., Israel, B. \& House, J. (1994). Chronic job insecurity among automobile workers: effects on job satisfaction and health. Social Science and medicine, 38, 1431-1437.

Hellgren, J., Sjöberg, A. \& Sverke, M. (1997). Intention to quit: Effects of job satisfaction and job perceptions. In F. Avallone, J. Arnold \& K. de Witte (Eds.). Feelings work in Europe. (pp. 415-423). Milano: Guerini.

Hellgren, J. \& Sverke, M. (2003). Does job insecurity lead to impaired well-being or vice versa? Estimation of cross-lagged effects using latent variable modeling. Journal of Organizational Behavior, 24, 215-236.

Hellgren, J., Sverke, M. \& Isaksson, K. (1999). A two-dimensional approach to job insecurity: consequences for employee attitudes and well-being. European Journal of Work and Organizational Psychology, 8, 179-195.

Kerkhof, P., Winder, A., Tamis, C., Te Brake, E. \& Klandermans, B. (2000). Arbeidsplaatsonzekerheid en participatie in de ondernemingsraad. Tijdschrift voor Arbeidsvraagstukken, 16, 150-163.

Kinnunen, U., Mauno, S., Nätti, J. \& Happonen, M. (1999). Perceived job insecurity: a longitudinal study among Finnish employees. European Journal of Work and Organizational Psychology, 8, 243-260.

Kjellberg, A. (1998). Sweden: restoring the model? In A. Ferner \& R. Hyman (Eds.). Changing Industrial Relations in Europe. (pp. 74-117). Oxford: Blackwell.
Landsbergis, P. (1988). Occupational stress among health care workers: a test of the job demands-control model. Journal of Occupational Behavior, 9, 217-239.

Lim, V. K. G. (1996). Job insecurity and its outcomes: Moderating effects of work-based and nonwork-based social support. Human Relations, 2, 171-194.

Mathieu, J.E. \& Zajac, D.M. (1990). A review and meta-analysis of the antecedents, correlates, and consequences of organizational commitment. Psychological Bulletin, 108, 171-194.

Meyer, J.P., Allen, N.J. \& Smith, C.A. (1993). Commitment to organizations and occupations: Extenstion and test of a three component conceptualization. Journal of Applied Psychology, 78, 538-551.

Purcell, K. \& Purcell, J. (1998). In-sourcing, out-sourcing, and the growth of contingent labour as evidence of flexible employment strategies. European Journal of Work and Organizational Psychology, 7, 39-59.

Regalia, I. \& Regini, M. (1998). Italy: the dual character of industrial relations. In A. Ferner \& R. Hyman (Eds.) Changing Industrial Relations in Europe. (pp. 459-503). Oxford: Blackwell.

Rosenblatt, Z. \& Ruvio, A. (1996). A test of a multidimensional model of job insecurity: the case of Israeli teachers. Journal of Organizational Behavior, 17, 587-605.

Rosenblatt, Z., Talmud, I. \& Ruvio, A. (1999). A gender-based framework of the experience of job insecurity and its effects on work attitudes. European Journal of Work and Organizational Psychology, 8, 197-217.

Roskies, E. \& Louis-Guerin, C. (1990). Job insecurity in managers: antecedents and consequences. Journal of Organizational Behavior, 11, 345-359.

Roskies, E., Louis-Guerin \& Fournier, C. (1993). Coping with job insecurity: how does personality make a difference? Journal of Organizational Behavior, 14, 617-630.

Shore, L.M., Tetrick, L.E., Sinclair, R.R. \& Newton, L.A. (1994). Validation of a measure of perceived union support. Journal of Applied Psychology, 79, 971-977.

Sverke, M. \& Goslinga, S. (2003). The consequences of job insecurity for employers and unions: exit, voice and loyalty. Economic and Industrial Democracy, 24, 241-270.

Sverke, M. \& Hellgren, J. (2001). Exit, voice, and loyalty reactions to job insecurity in Sweden: Do unionized and non-unionized employees differ? British Journal of Industrial Relations, 2, 167-182.

Sverke, M., Hellgren, J. \& Näswall, K. (2002). No security: a meta-analysis and review of job insecurity and its consequences. Journal of Occupational Health Psychology, 3, 242-264.

Sverke, M., Hellgren, J., Näswall, K., Chirumbolo, A., De Witte, H. \& Goslinga, S. (2001). European unions in the wake of flexible production: technical report on the data sets used in a SALTSA project. SALTSA report 2000:1. Stockholm: Ntional Institute for Working Life and SALTSA.

Van Vuuren, C.V., Van Gastel, J.H.M. \& Klandermans, P.G. (1988). Banen in gevaar: de beleving van onzekerheid over de arbeidsplaats. Gedrag \& Organisatie, 1, 14-29.

Van Vuuren, T. (1990). Met ontslag bedreigd: werknemers in onzekerheid over hun arbeidsplaats bij veranderingen in de organisatie. Amsterdam: VU Uitgeverij.

Van Vuuren, T., Klandermans, B., Jacobson, D. \& Hartley, J. (1991). Employees' reactions to job insecurity. In J. Hartley, D. Jacobson, B. Klandermans \& T. van Vuuren. Job insecurity: coping with jobs at risk. (pp. 79-103). London: Sage publications. 